\title{
化学物質過敏症研究へのメタボロミクスの応用
}

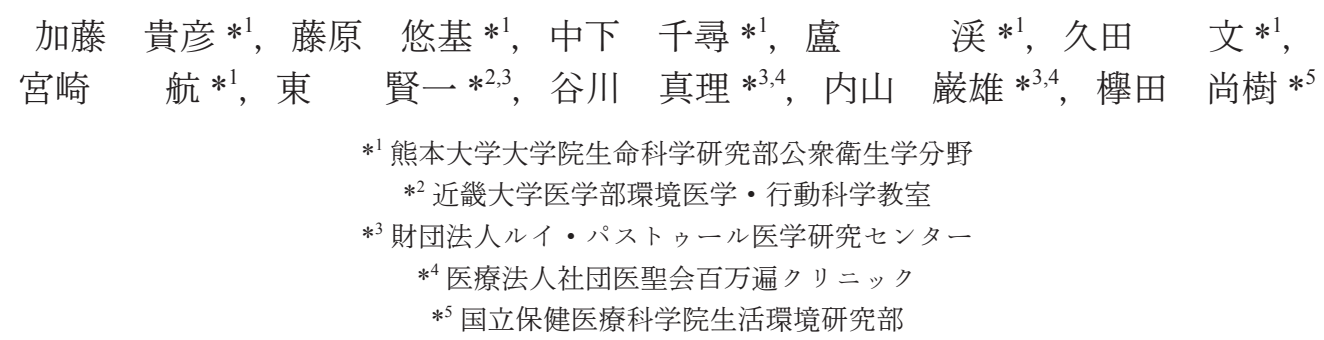

\section{Application of Metabolomics to Multiple Chemical Sensitivity Research}

\author{
Takahiko KATOH*1, Yuki FUJIWARA*1, Chihiro NAKASHITA*1, Xi LU*1, Aya HISADA*1, \\ Wataru MIYAZAKI*1, Kenichi AZUMA*2,3, Mari TANIGAWA*3,4, Iwao UCHIYAMA*3,4 \\ and Naoki KUNUGITA*5 \\ *lDepartment of Public Health, Faculty of Life Sciences, Kumamoto University \\ *2Department of Environmental Medicine and Behavioral Science, Kinki University Faculty of Medicine \\ ${ }^{*}$ Division of Basic Research, Louis Pasteur Center for Medical Research \\ ${ }^{*}$ Hyakumanben Clinic \\ *5 Department of Environmental Health, National Institute of Public Health
}

\begin{abstract}
Multiple chemical sensitivity (MCS) is an acquired chronic disorder characterized by nonspecific symptoms in multiple organ systems associated with exposure to low-level chemicals. Diagnosis of MCS can be difficult because of the inability to assess the causal relationship between exposure and symptoms. No standardized objective measures for the identification of MCS and no precise definition of this disorder have been established. Recent technological advances in mass spectrometry have significantly improved our capacity to obtain more data from each biological sample. Metabolomics comprises the methods and techniques that are used to determine the small-level molecules in biofluids and tissues. The metabolomic profile - the metabolome - has multiple applications in many biological sciences, including the development of new diagnostic tools for medicine. We performed metabolomics to detect the difference between 9 patients with MCS and 9 controls. We identified 183 substances whose levels were beyond the normal detection limit. The most prominent differences included significant increases in the levels of both hexanoic acid and pelargonic acid, and also a significant decrease in the level of acetylcarnitine in patients with MCS. In conclusion, using metabolomics analysis, we uncovered a hitherto unrecognized alteration in the levels of metabolites in MCS. These changes may have important biological implications and may have a significant potential for use as biomarkers.
\end{abstract}

Key words: chemical sensitivity（化学物質過敏症）, metabolome（メタボローム）, fatty acid (脂肪酸), acetylcarnitine（アセチルカルニチン）, case control study（症例・対照研究）

受付 2015 年 4 月 25 日，受理 2015 年 5 月 7 日

Reprint requests to: Takahiko KATOH

Department of Public Health, Faculty of Life Sciences, Kumamoto University, 1-1-1 Honjou, Chuo-ku, Kumamoto 860-8556, Japan TEL: +81(96)373-5112, FAX: +81(96)373-5113

E-mail: katoht@gpo.kumamoto-u.ac.jp

\section{1.はじめに}

空気質に起因し，シックハウス症候群との関連がいわ れる疾患概念として化学物質過敏症がある。化学物質過 敏症の概念のスタートは，1987 年，化学物質に曝露さ れる機会の多い労働者を診察していたカレンが，過去に 大量の化学物質に一度に曝露された後，または長期間慢 
性的に化学物質の曝露を受けた後, 非常に微量の化学物 質に再接触した際に見られる不快な臨床症状を，MCS (Multiple chemical sensitivity, 多種化学物質過敏状態) と提唱したことによる（1）。わが国では，固有の名称と して「化学物質過敏症」と呼ぶことが多いが，カレンの 提唱した概念と同一であるとは必ずしも言えず，「シッ クハウス症候群は化学物質過敏症の一つの病態」,「化学 物質過敏症はシックハウス症候群の重症化した病態」な どの解説がなされている。しかし, 住居といら空間を離 れても, 化学物質過敏症のような健康障害が一定数存在 することは事実であり，患者と向き合ら臨床現場では， 患者からも医師からも, その客観的診断方法の確立, 治 療法の開発, 病態の解明が望まれている。

我々は，化学物質過敏症のような未知の病態が推定さ れる疾患概念に対し, 最近の研究技術の一つであるメタ ボロミクスを用いて, 病態解明の糸口をつかもらと研究 を実施している。

\section{2.メタボロミクスとは}

従来の研究は, 生物のある現象に注目し, 従来の知見 をもとに仮説を設定し，それを証明するといら演繹的な 方法が標準的であった。一方，近年は仮説を設定せずに データを収集し，得られたデータから新しい知見を抽出 するといら帰納的な方法が利用されつつある。この流れ に乗って，ゲノミクス，トランスクリプトミクス，プロ テオミクスとともに，代謝物質を網羅的に解析するメタ ボロミクスが注目されている（図 1）（2）。メタボロー ムは「代謝物総体」といら概念である。すなわちメタボ ロミクスは，他のオミクス技術と同様に，一つの試料か ら多くの標的物質を一度に測定できる技術である。その ため, 測定対象物質の測定間䛊差や研究対象の個体間䛊 差を最小化することが可能である。また高価ではあるが, 分析能力の高い測定機器を用いることによって，前処理 操作を簡略化できることも, 労力の低減とともに誤差要 因を低減する効果がある（表 1）。

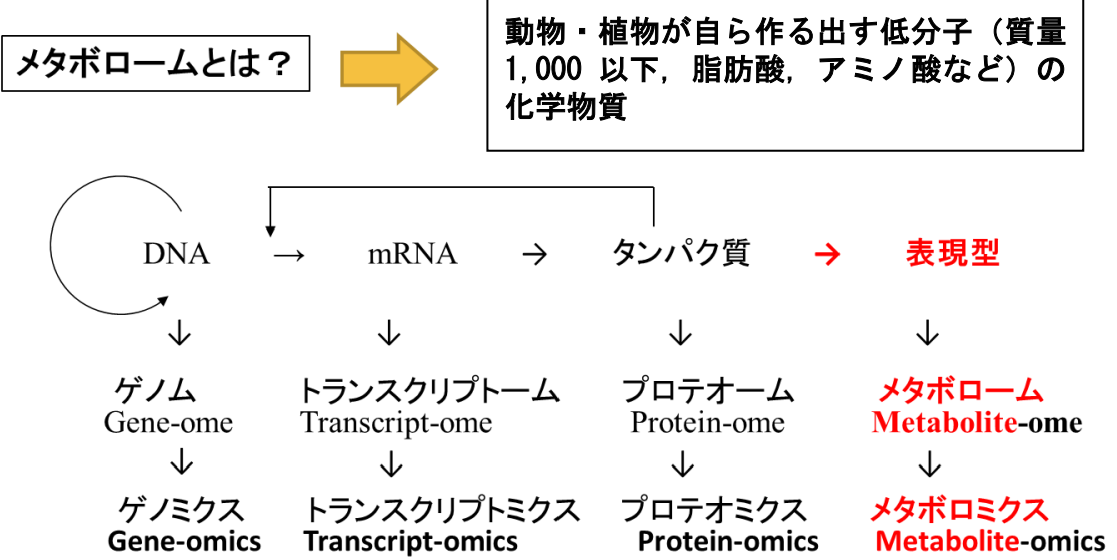

図 1 オミクス解析のなかでのメタボロミクスの位置づけ。(「HMT×タボローム解析技術のご紹介」資料より（2），一部改編， 2013)

表 1 他のオミクスと比較し, メタボロミクスの利点と限界点

\begin{tabular}{|c|c|}
\hline 特徵 & 利点 \\
\hline 対象物質数が少ない & $\begin{array}{l}\text { 解析が容易。 } \\
\text { ヒトゲノム約 } 23,000, \text { プロテオームは約 } 1,000,000 \text { であるのに対して, メタボロームは約 } 4,000 \text { 。 }\end{array}$ \\
\hline 低分子である & $\begin{array}{l}\text { 従来の知見・経験が活かせる。 } \\
\text { 種々の代謝物に関する生理学的・病理学的意義が蓄積されている。 }\end{array}$ \\
\hline 表現型に近い & 結果に関する直接の原因を探しやすい。 \\
\hline 動物種特異性が存在しない & $\begin{array}{l}\text { 多くの代謝物は，多くの種において共通。 } \\
\text { 種ごとに異なるゲノム情報や分析法を用意する必要がなく，その分析手法が共通である。 }\end{array}$ \\
\hline 誤差の最小化 & $\begin{array}{l}\text { 多数の物啠を一度に測定できる。 } \\
\text { 実験間誤差や測定間誤差が小さい。 }\end{array}$ \\
\hline 特徵 & 限界点 \\
\hline 因果関係 & $\begin{array}{l}\text { 原因か結果かがわからない } \\
\text { コストが下がり，時間的変動が観察できれば解決可能か }\end{array}$ \\
\hline 臟器特異性 & 血液は運搬系であり, 臟器の代謝異常はみえない。逆に考光れば，血液は全身の反映でもある。 \\
\hline 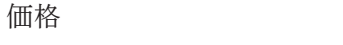 & 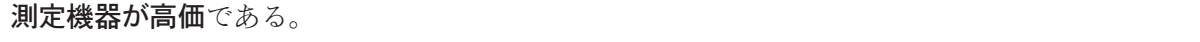 \\
\hline 対象物質の最適測定条件 & すべての対象物質に最適な測定条件を設定することは困難である． \\
\hline
\end{tabular}


表 2 症例群と対照群の属性

\begin{tabular}{lcc}
\hline \multirow{2}{*}{ 変数 } & 症例群 & 対照群 \\
\cline { 2 - 3 } & Mean $\pm \mathrm{SD}$ & Mean $\pm \mathrm{SD}$ \\
\hline 女性 $($ 割合 $)$ & $9(100 \%)$ & $9(100 \%)$ \\
年令 $($ 範囲) & $44.2 \pm 8.8$ & $41.1 \pm 9.1$ \\
& $47-62$ & $46-62$ \\
身長 $(\mathrm{cm})$ & $158.8 \pm 8.0$ & $157.3 \pm 4.4$ \\
体重 $(\mathrm{kg})$ & $51.9 \pm 8.3$ & $52.8 \pm 4.1$ \\
Body Mass Index & $20.5 \pm 2.1$ & $21.3 \pm 1.0$ \\
$\left(\right.$ 体重 $(\mathrm{kg}) /$ 身長 $\left.(\mathrm{m})^{2}\right)$ & & \\
\hline
\end{tabular}

Value is mean $\pm \mathrm{SD}$. A $P$-value of 0.05 was considered statistically significant. Statistical analysis was carried out using the Statistical Package SPSS Version 21.

\section{3. 化学物質過敏症に関する症例・対照研究}

\section{3-1 対象と方法}

対象者は, 京都市内の病院にて化学物質過敏症之診 断された症例群（女性）9名と年齢と性がマッチング （土2 歳）された対照群（女性）9名であり，年齢は46歳 〜 62 歳の範囲である (表 2)。化学物質過敏症の診断は, 化学物質過敏症を専門とする医師が，診察と質問票の久 コアを参考に診断し，一般的検査で明らかな合併症を有 したり，精神疾患が疑われる人は除外している。対照群 は, 一般的健康診断で異常値の認められなかった健常者 9 名である。今回の症例群はすべて食後採血であり, 対 照群は 5 名が食前採血，4名が食後採血であった。薬剤 の服用歴については, 症例群のうち 1 名が抗らつ薬と精 神安定剂を常用し, 対照群では 1 名が精神安定剂を常用 していた。

対象者から，EDTA-2K が入った採血管にて採血後, すぐに遠心分離し, 得られた血漿は測定までー $80^{\circ} \mathrm{C}$ に 保存した。採取された検体は, 一部は株式会社エスアー ルエルに依頼し臨床検查を実施した。メタボロミクス解 析については, ヒューマン・メタボローム・テクノロジー 株式会社（以下，HMT）に分析を依頼した。分析は, 同時解析で症例と対照はランダムに測定した。

本研究は, 財団法人ルイ・パストゥール医学研究セン ターと百万遍クリニックに設置されている倫理委員会の 承認（それぞれ，2010年 10 月 5 日，LPC.11，2010年 9 月 28 日, 倫 HB22-1）を得て抒り, 熊本大学では匿名可 された分析結果の検討のみを行った。調査対象者には, 文書と口頭で研究概要を説明するとともに, 調査協力が 任意であることを説明し, 文書によって研究参加への同 意を得た。

\section{3-2 結果}

\section{3-2-1 血液・生化学的検查}

末梢血液一般検查值, 一般生化学検査值汇関し, 症例 群と対照群のあいだに統計学的に有意な差は認められな かった（表3）。
表 3 症例群と対照群の血液・生化学検査の結果

\begin{tabular}{lcc}
\hline \multirow{2}{*}{ 変数 } & 症例群 & 対照群 \\
\cline { 2 - 3 } & Mean $\pm \mathrm{SD}$ & Mean $\pm \mathrm{SD}$ \\
\hline 白血球数 $\left(\times 10^{2} / \mu \mathrm{l}\right)$ & $51.1 \pm 20.0$ & $49.0 \pm 11.3$ \\
赤血球数 $\left(\times 10^{4} / \mu \mathrm{l}\right)$ & $441.7 \pm 22.6$ & $451.9 \pm 35.7$ \\
ヘモグロビン量 $(\mathrm{g} / \mathrm{dl})$ & $13.1 \pm 0.6$ & $13.5 \pm 1.4$ \\
血小板数 $\left(\times 10^{4} / \mu \mathrm{l}\right)$ & $24.6 \pm 6.3$ & $28.2 \pm 6.0$ \\
総蛋白 $(\mathrm{g} / \mathrm{dL})$ & $7.5 \pm 0.3$ & $7.5 \pm 0.4$ \\
アルブミン $(\mathrm{g} / \mathrm{dL})$ & $4.5 \pm 0.3$ & $4.6 \pm 0.3$ \\
$\mathrm{LDL}$ コステロール $(\mathrm{g} / \mathrm{dL})^{\mathrm{a}}$ & $123.8 \pm 19.1$ & $125.6 \pm 32.6$ \\
$\mathrm{HDL}$ コレステロール $(\mathrm{g} / \mathrm{dL})^{\mathrm{a}}$ & $79.0 \pm 24.3$ & $78.4 \pm 16.4$ \\
中性脂肪 $(\mathrm{g} / \mathrm{dL})^{\mathrm{a}}$ & $92.2 \pm 44.3$ & $122.6 \pm 81.9$ \\
$\mathrm{AST}(\mathrm{GOT})(\mathrm{U} / \mathrm{L})^{\mathrm{b}}$ & $18.6 \pm 6.5$ & $19.2 \pm 4.5$ \\
$\mathrm{ALT}(\mathrm{GPT})(\mathrm{U} / \mathrm{L})^{\mathrm{b}}$ & $14.2 \pm 6.6$ & $17.7 \pm 7.0$ \\
$\gamma$-GT $(\gamma-\mathrm{GTP})(\mathrm{U} / \mathrm{L})^{\mathrm{b}}$ & $20.6 \pm 13.8$ & $22.2 \pm 7.5$ \\
クレアチニン $(\mathrm{mg} / \mathrm{dL})$ & $0.5 \pm 0.1$ & $0.6 \pm 0.1$ \\
\hline
\end{tabular}

Value is mean $\pm \mathrm{SD}$. A $P$-value of 0.05 was considered statistically significant. Statistical analysis was carried out using the Statistical Package SPSS Version 21.

If variables were not normally distributed, the statistical analyses were performed after variables transformed ${ }^{a}$ Square root and ${ }^{b}$ logtransformed.

\section{3-2-2 メタボローム解析}

18 検体の血漿検体について, “キャピラリ一電気泳動 装置（capillary electrophoresis: CE）を飛行時間型質量分 析装置（time-of-flight mass spectrometry: TOFMS）に接続 した分析装置 (CE-TOFMS)”を用いてメタボローム解 析を行った。HMT 代謝物質ライブラリー及び KnownUnknown ピークライブラリーに登録された物質から 904 のアノテーション（機能について注釈がある）がある物 質が得られ，そのなかで 183 物質が検出限界以上であっ た。得られた代謝産物に関し, HMTによって開発され た Sample Stat ver3.14 を用いて解析を行った。

本研究では, 対象者の食事拱取状況をマッチングする ことができなかったため, (1)対照群 9 名のなかで食前採 血群（5名 control 1) と食後採血群（4名 control 2) (2) 症例群 9 名（食後採血）と対照群 9 名 (control 1+2) と比較解析し, 次に食事摂取を考慮し, (3)症例群 9 名（食 後採血）と対照群 4 名（control 2) で比較解析を行った。 症例群と対照群の群間の相対面積比を算出し, Welch の $t$-検定を実施し，個別に検討を重社た。その結果， 中鎖脂肪酸であるへキサン酸（hexanoic acid（C6:0） と ペラゴン酸（Pelargonic acid（C9:0））は，食事の影響が 認められないにもかかわらず (図 2,3, それぞれの上図), 症例群 9 名（食後採血）と対照群 9 名（食後十食前採血） 比較で, 症例群に拈いて統計学的に有意な高值が認めら れ（図 2，3，それ皆れの中図）（それぞれ $\mathrm{P}=0.001$, $\mathrm{P}=0.002$ ), 症例群 9 名（食後採血）と対照群 5 名（食 後採血) 比較でも, 症例群は対照群と比較し, 統計学的 に有意な高值が認められた（図 2, 3, それぞれの下図）(そ れぞれ $\mathrm{P}=0.001, \mathrm{P}=0.004)$ 。 


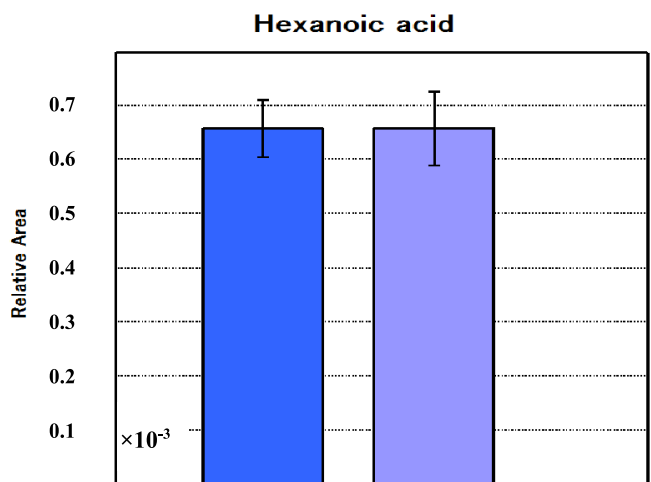

Control 1 Control 2

Hexanoic acid

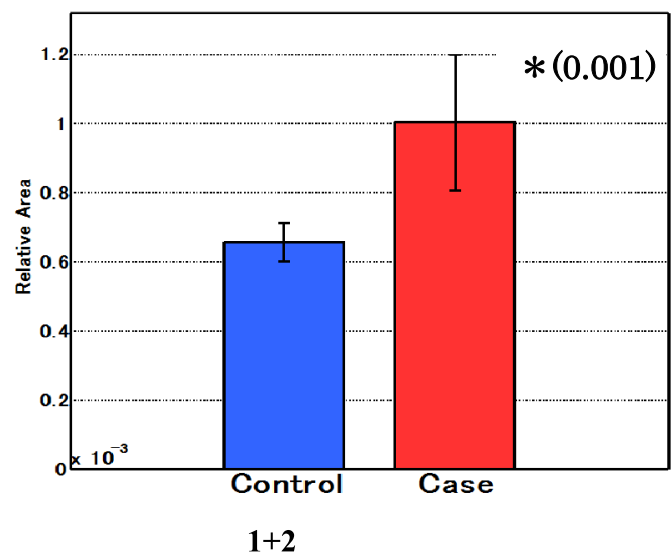

Hexanoic acid

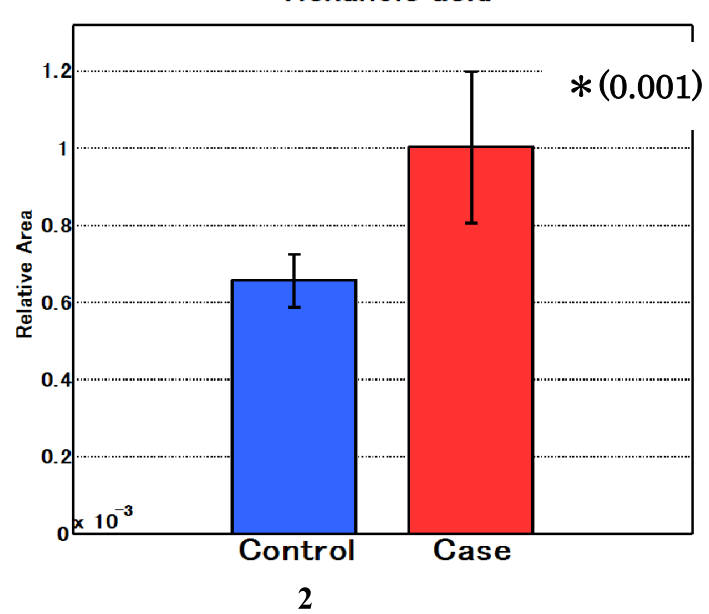

図 2 ヘキサン酸の比較分析結果。上: 対照群内の食事影響比 較, control 1 群（食前） - $(n=5)$ control 2 群（食後） $(n=4)$ 。 中: 症例群 $(\mathrm{n}=9)$ - 対照群 $(\mathrm{n}=9$, control $1+2$ 群) の比較。下: 症例群 $(n=9)$ - 対照群（食後） ( $n=4$, control 2 群) の比較。 $* 2$ 群間の相対面積比を算出し, Welch の $t$-検定を実施。 $\mathrm{P}<0.05$

一方，アセチルカルニチンは，食事や採血時刻の影響 によって高值傾向が認められるにもかかわらず（図 4, 上図), 症例群 9 名（食後採血）と対照群 9 名（食後十 食前採血）比較では, 症例群に抒いて統計学的に有意な
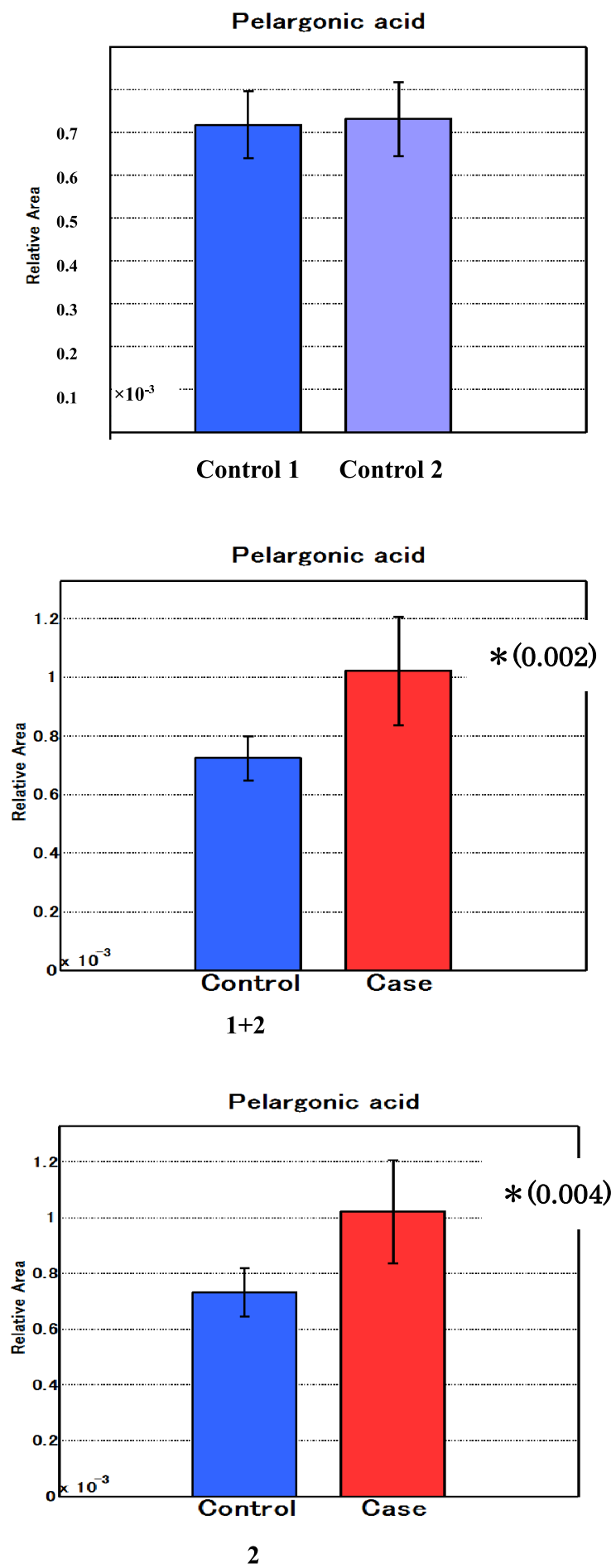

図 3 ペラルゴン酸の比較分析結果。上 : 対照群内の食事影響 比較, control 1 群（食前） $(n=5) \operatorname{control} 2$ 群（食後） $(n=4)$ 。 中: 症例群 $(n=9)$ - 対照群 $(n=9$, control $1+2$ 群) の比較。下: 症例群 $(n=9)$ - 対照群（食後） $(n=4$, control 2 群）の比較。 * 2 群間の相対面積比を算出し, Welch の $t$-検定を実施。 $\mathrm{P}<0.05$

低值が認められ（図 4, 中図） $(P=0.016 ）$, 症例群 9 名（食 後採血）と対照群 5 名（食後採血）に打いても, 症例群 は対照群と比較し統計学的に有意な低值が認められた (図 4, 下図) $(P=0.011) 。$ 


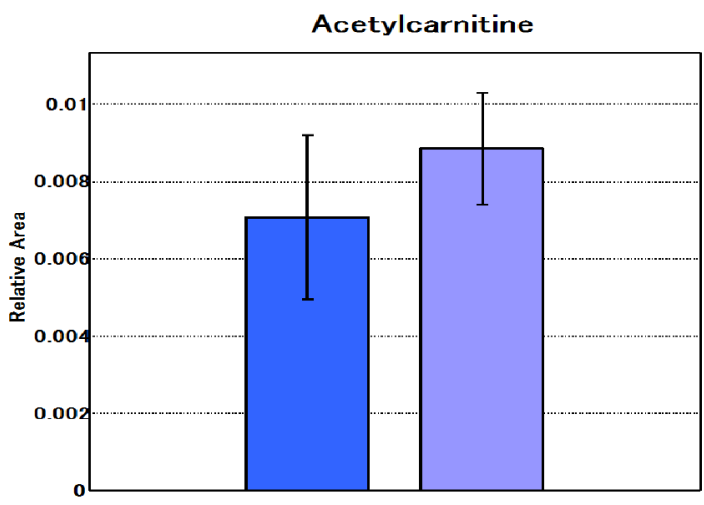

Control 1 Control 2

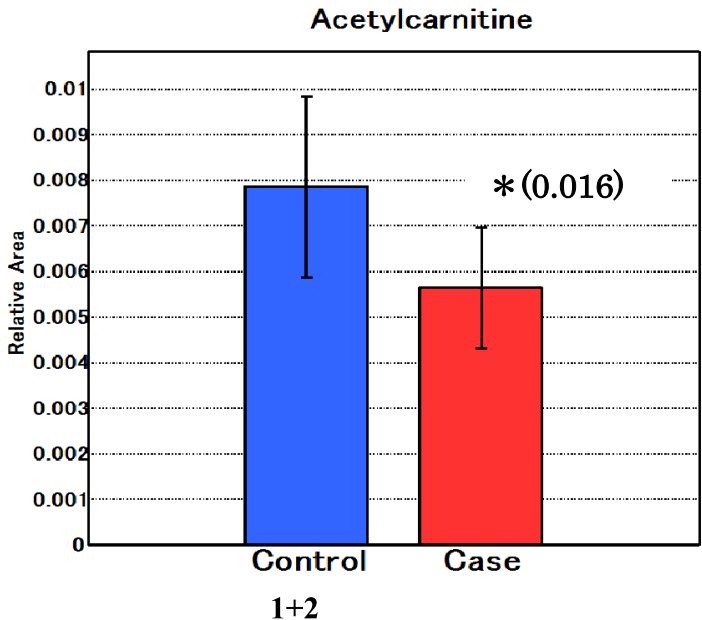

Acetylcarnitine

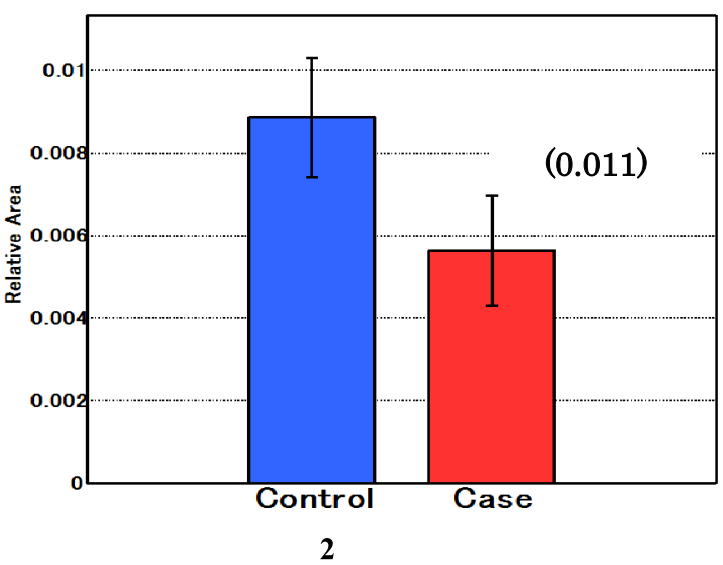

図 4 アセチルカルニチンの比較分析結果。上 : 対照群内の食 事影響比較, control 1 群・(食前) ( $\mathrm{n}=5)$ control 2 群（食後）( $\mathrm{n}$ =4)。中: 症例群 $(n=9)$ - 対照群 $(n=9$, control $1+2$ 群 $)$ の 比較。下: 症例群 $(n=9)$ - 対照群（食後） $(n=4$, control 2 群) の比較。* 2 群間の相対面積比を算出し, Welch の $t$-検定を実施。 $\mathrm{P}<0.05$

\section{3-3 考察}

今回の研究結果では, 症例群において中鎖脂肪酸の統 計学的に有意な高值とアセチルカルニチンの統計学的に 有意な低值が認められた。
脂肪酸は油脂を構成する成分のひとつで，数個から数 10 個の炭素が鎖のよらに繋がった構造をしている。そ の炭素の数から，短鎖脂肪酸，中鎖脂肪酸，長鎖脂肪酸 の 3 群に分けられ，長鎖脂肪酸はさらに，ミリスチン酸 (C14:0)，パルミチン酸 $(\mathrm{C} 16: 0)$ ，ステアリン酸（C18:0） のような飽和脂肪酸とオレイン酸 $(\mathrm{C} 18: 1)$ リノール酸 $(\mathrm{C} 18: 2), \alpha$-リノレン酸（C18:3）, アラキドン酸（C20:4）, エイコサペンタエン酸 (EPA: C20:5), ドコサヘキサエ ン酸 (DHA: C22:6) のような不飽和脂肪酸に分類される。 一般的な油は，分子の鎖が長い長鎖脂肪酸によって構成 されているが，中鎖脂肪酸は鎖の長さがその 6 個から 12 個の脂肪酸である。代表的な中鎖脂肪酸にはカプリ ル酸 $(\mathrm{C} 8: 0)$ ，カプリン酸（C10:0），ラウリン酸（C12:0） があり, 飽和脂肪酸は炭素の数が多いほど融点が高くな るといら性質をもっている。

今回の我々の分析結果では, 化学物質過敏症の症例群 に执いて，中鎖脂肪酸の増加が認められた。最近，中鎖 脂肪酸はココナッッやパームフルーッなどヤシ科植物の 種子の核の部分に含まれる天然成分として注目されてお り, 長鎖脂肪酸よりも消化吸収が早く, 肝蔵で分解され やすく，エネルギーとなりやすい特徵がある。従って脂 肪酸のなかで最も脂肪になりにくく，健康に望ましい脂 肪酸だといわれている（3）。また中鎖脂肪酸は，長鎖脂 肪酸と異なりカルニチンと結合しなくてもミトコンドリ ア内に輸送される。その後, 脂肪酸は $\beta$ 酸化によってア セチル CoA となり, クエン酸回路を通じて ATP（エネ ルギー）が生成される。

症例群に括いて，中鎖脂肪酸值，特にへキサン酸值と ペラゴン酸值が高い結果が得られたメカニズムは現時点 では明らかではない。一つの仮説としては, ミトコンド リア脂肪酸酸化酵素の一つである中鎖アシル-CoA 脱水 素酵素 (medium-chain acyl-CoA dehydrogenase: MCAD) の異常が考えられる。脂肪酸が分解されないと, 各蔵器 に脂肪が蓄積し脂肪変性が生じ，心笳障害や筋力低下な ぞを来たすことが報告されており（4）、これらは化学物 質過敏症の臨床症状と類似している。これまでに中鎖脂 肪酸と化学物質過敏症との関連についての報告はなく,

今後，検討を重亦ていきたいと考えている。

カルニチンは生体の脂質代謝に関与寸る物質であり, アミノ酸から生合成される誘導体である。生体内では, カルニチンの約 $10 \%$ がアセチルカルニチンとして存在 している。立体異性体のらち脂質代謝に利用されるのは L-カルニチンのみである。カルニチンはエネルギーを産 生するために，アシル脂肪酸を燃焼の場であるミトコン ドリア内部に運搬する。その後, カルニチンはカルニチ ンアセチルトランスフェラーゼによってアセチルカルニ チンとなり，ミトコンドリア外の細胞質へ輸送される。 アセチルカルニチンは, 細胞質でカルニチンとアセチル -CoA に分解され, アセチル-CoA は, アセチル-CoA ル ボキシラーゼにより脂肪酸に合成される。またアセチル カルニチンは, 血液脳関門を通過し脳内に到達し, アセ 
チルコリンの合成, シナプスからの放出といら一連のプ ロセスを促進することが報告されている（5）。アセチル コリンは副交感神経や運動神経の末端から放出される神 経伝達物質である。アセチルコリンの減少は, 集中力や 記憶力の低下やアルッハイマー病との関連が指摘されて 扣り, アセチルカルニチンがアルッハイマ一病初期症状 に対する改善効果を有することが報告されている(6)。 以上のような報告から，アセチルカルニチンの減少は, 化学物質過敏症患者に打ける疲労感, 不安, らつ状態な ぞの精神症状を引き起こしている可能性が示唆される。

今回の研究結果では, 有意差は認められなかったもの の, アセチルカルニチンと同様にカルニチンの低值も観 察された。化学物質過敏症の類似疾患の一つとして慢性 疲労症候群があるが, これまで, 慢性疲労症候群の患者 でカルニチンが欠乏していることや(7), アシルカルニ チンが疲労の程度と相関しているといらことが報告され ている (8)。さらにカルニチン欠乏マウスを用いた実験 研究から, 脂肪酸代謝障害によって血中脂肪酸が増加し, その結果，自発活動量が低下寸ることが報告されている (9)。カルニチン欠乏マウスでは心肥大が認められ，そ の原因はエネルギー欠乏によって生じたのではなく，脂 肪酸そのものの毒性に起因することを証明する実験結果 も報告されている(10)。

今回の研究結果は, サンプル数も少なく, 断面調査の ため因果関係には踏久込むことはできない。しかしあえ て推察すれば, 化学物質過敏症ではカルニチン, アセチ ルカルニチンの減少が生じ，それらの直接的影響や，脂 肪酸の利用障害による影響, そして脂肪酸そのものの毒 性による自発活動量の低下や臓器障害が引き起こされて いる可能性が示唆される。アセチルカルニチンはまだわ が国では販売されていないが，カルニチンはサプリメン トとして販売されて扣り, その補給によって化学物質過 敏症の症状が軽減される可能性が期待される。

\section{4. おわりに}

メタボロミクスは，ハイスループットの魅力的な分析 方法であるが，食事摄取や日内変動など個人的な生活状 況によって大きな影響を受けやすい課題を抱えている。 実際，実験条件をそろえやすい培養細胞や動物実験を除 くと，人の研究では個人間のばらつきが大きく，同一人 をつかった介入研究以外, 十分な成果が得られていると はいえない。また人の代謝物とライフスタイルとの関連 などの基本的な情報も少ない。従って，個人間変動を包 括した症例・対照研究への利用には，少なくとも，年齢， 性別, 食事や採血時間を可能な限りマッチングする必要 がある。今後, 我々もこれらの条件をできる限りそろえ, 化学物質過敏患者の症例・対照研究デザインやケース・ クロスオーバーデザインによってメタボローム解析を実 施していく予定である。あわせて，今後のメタボロミク
スの普及を考光，継続的にその有効性と課題も検討して いきたいと考えている。

本稿が今後の化学物質過敏症患者の予防や治療の礎と なることを願っている。

\section{謝辞}

本研究の一部は，厚生労働科学研究費補助金 健康安 全・危機管理総合研究事業（代表者欅田尚樹），JSPS 科 研費 22590568 （代表者内山嚴雄）の助成で実施された。

利益相反なし

\section{文献}

(1) Cullen MR. The worker with multiple chemical sensitivities: An overview. Occup Med 1987;2:655-661.

（2）HMTメタボローム解析技術のご紹介の資料，ヒュー マン・メタボローム・テクノロジー株式会社 (HMT), 2013.

( 3 ) Kasai M, Nosaka N, Maki H, Negishi S, Aoyama T, Nakamura $\mathrm{M}$, et al. Effect of dietary medium- and longchain triacylglycerols (MLCT) on accumulation of body fat in healthy humans. Asia Pac J Clin Nutr 2003;12:151-160.

(4) Purevsuren J, Hasegawa Y, Fukuda S, Kobayashi H, Mushimoto Y, Yamada K, et al. Clinical and molecular aspects of Japanese children with medium chain acyl-CoA dehydrogenase deficiency. Mol Genet Metab 2012;107: 237-240.

( 5 ) Ando S, Tadenuma T, Tanaka Y, Fukui F, Kobayashi S, Ohashi Y, et al. Enhancement of learning capacity and cholinergic synaptic function by carnitine in aging rats. Neurosci Res 2001;66:266-271.

( 6 ) Hudson S, Tabet N; Cochrane Dementia and Cognitive Improvement Group. Acetyl-1-carnitine for dementia. Cochrane Database Syst Rev 2003;(2):CD003158. doi: 10.1002/14651858.CD003158

( 7 ) Lavergne MR, Cole DC, Kerr K, Marshall LM. Functional impairment in chronic fatigue syndrome, fibromyalgia, and multiple chemical sensitivity. Can Fam Physician 2010; 56:e57-e65.

( 8 ) Kuratsune H, Yamaguti K, Takahashi M, Misaki H, Tagawa $\mathrm{S}$, Kitani T. Acylcarnitine deficiency in chronic fatigue syndrome. Clin Infect Dis 1994;Suppl 1:S62-S67.

( 9 ) Yoshida G, Li MX, Horiuchi M, Nakagawa S, Sakata $\mathrm{M}$, Kuchiiwa $\mathrm{S}$, et al. Fasting-induced reduction in locomotor activity and reduced response of orexin neurons in carnitine-deficient mice. Neurosci Res 2006;55:78-86.

(10) Jalil MA, Horiuchi M, Wakamatsu M, Li MX, Begum L, Suzuki K, et al. Attenuation of cardiac hypertrophy in carnitine-deficient juvenile visceral steatosis (JVS) mice achieved by lowering dietary lipid. J Biochem 2006;139: 263-270. 